\title{
Criminalization of Sexual Acts in Jordanian Law (Comparative Study)
}

\author{
Hamzeh Abu Issa ${ }^{1, *}$ and Mohammad Al-Taraira ${ }^{2}$ \\ ${ }^{1}$ Dean of Faculty of Law, Applied Science Private University, Jordan \\ ${ }^{2}$ Dean of Faculty of Shariah and Islamic Studies, Applied Science Private University, Jordan
}

\begin{abstract}
This article aimed to clarify the opinion of the Jordanian legislator regarding the criminalization of sexual acts in comparison to the position of the monotheistic religions and contemporary laws, in addition to knowing the Jordanian society's view of criminalizing sexual acts. By looking at the Jordanian legal texts related to the subject, it became apparent to researchers that the Jordanian legislator adopts the principle of sexual freedom like other legislators in other countries, despite this violation of Islamic law, which is the official religion of the state according to the Jordanian constitution. In order to achieve the objectives of the study, the researchers adopted the descriptive and analytical approach that reads the opinion of the Jordanian legislator, the monotheistic religions, and contemporary laws in criminalizing sexual acts. Using the results of a questionnaire designed for the purpose of knowing the views of the Jordanian society on the principle of sexual freedom. This questionnaire was distributed to a random sample of 1000 people. The article reached a number of conclusions, including that (84)\% of Jordanian society do not accept sexual freedom for religious, moral and social reasons. In light of the results of the article, the authors recommended abolishing the principle of sexual freedom from Jordanian law and calling on the Jordanian legislator to reconsider texts related to the criminalization of sexual acts in line with the culture of society.
\end{abstract}

Keywords: Philosophy of law, sexual acts, sexual freedom, Jordanian law, religions, criminal law.

\section{INTRODUCTION}

The matter of regulating the practice of sexual acts is one of the most important tasks of the law in the state. Since ancient times, laws have been involved in organizing the sexual life of citizens, for fear of the chaos that leads to conflicts. It is well established that the law must meet the needs of society and protect the basic interests in it, and from this standpoint, laws have differed across time and place by adopting the philosophy of criminalizing sexual acts. Researchers discussed the arguments for and against the principle of sexual freedom (De Marneffe 2013; Green 2013). It can be said that there are three main directions of criminalization:

The first: absolute criminalization of sexual acts outside marriage.

The second: relative criminalization of sexual acts.

The third: adopting the principle of sexual freedom.

This article aims to know the position of the Jordanian legislator on criminalizing sexual acts in comparison to the position of the monotheistic religions and contemporary laws that affect the legislator, to reach the extent of the relationship between legislation and religion on the one hand, and on the other hand

*Address correspondence to this author at the Dean of Faculty of Law, Applied Science Private University, Jordan; E-mail: hamza_abuissa@msn.com the extent to which Jordanian law has been affected by modern laws. The article also aims to know the Jordanian society's opinion of the principle that its legislator followed.

Whereas the search for a policy of law and religion in the field of criminalizing sexual acts requires careful consideration of the texts, their interpretation and analysis, the article used the descriptive and analytical method to reach conclusions, given that the general principle was not stipulated in clear and explicit texts.

As for knowing the opinion of the Jordanian society and the extent of its acceptance of the principle adopted by Jordanian law, it will be reached by analyzing a specially designed questionnaire and distributed it to a random sample of 1000 .

After explaining the significance of the sexual act, this article presents the philosophy of the Heavenly religions in criminalization, and then the philosophy of criminalization in comparative countries, and the position of Jordanian legislation on that, discuss these philosophies, and finally examines the extent to which the Jordanian society accepts the philosophy adopted by the legislator regarding sexual acts.

\section{THE MEANING OF SEXUAL ACTS}

To define the scope of the research, it is necessary to define what is meant by the sexual acts that are the subject of this article, which are acts related - in some 
way - to sexual life (Hosni 1984). Sexual acts include sexual practices, which are all acts that are considered - in the discretion of the ordinary person - in response to the call of sex, regardless of the level of obscenity in them (Abu Amer1985). Where the idea of sexual activity is linked to the sexual instinct (Hassan 2004).

The idea of the sexual act is broad in scope: it is not limited to the normal sexual relationship, but also extends to the unnatural sexual relationship, which aims to satisfy sexual desire. This idea also extends to the partial sexual relationship in which neither party has reached full sexual satisfaction, even if the goal is merely to arouse sexual arousal. Rather, this idea extends to every act that is - according to the normal course of affairs - a prelude to a sexual connection, such as touching the victim's body, or a means to arouse his desire, such as hugging or kissing. The lesson is the nature of the act and its objective direction, and the lesson is not with the purpose of the perpetrator, and whether he intends to stand with it or wants to follow it with other, more obscene actions. The idea of a sexual act is also expanded for every act that violates the sexual modesty of those who see it, even if it did not occur on his body, as if the perpetrator revealed his genitals to the victim, or began a sexual relationship in front of him, and it goes without saying that scratching sexual modesty gives the act a clear sexual color (Hosni 1984).

\section{THE PHILOSOPHY OF HEAVENLY RELIGIONS IN} THE CRIMINALIZATION OF SEXUAL ACTS

\section{a. Judaism}

It is evident that the penalties in Judaism were severe and strict because they were applied to an anarchic society, which crime and immorality were widespread. The death penalty in Judaism is prescribed for thirty crimes (Al-Batrawi 1996).

In the field of sexual crimes, we find that the death penalty was prescribed for the following crimes:

A. Adultery in some cases, namely: Adultery with a married woman (Deuteronomy 22/22: If a man is found lying with a woman married to a husband, then they shall both of them die, both the man that lay with the woman). Adultery with an engaged woman (Deuteronomy 22/23: If a damsel that is a virgin be betrothed unto a husband, and a man find her in the city, and lie with her; Then ye shall bring them both out unto the gate of that city, and ye shall stone them with stones that they die; the damsel, because she cried not, being in the city; and the man, because he hath humbled his neighbor's wife: so thou shalt put away evil from among you). Adultery in some degrees of incest (Leviticus 20/10-12: And the man that committeth adultery with another man's wife, even he that committeth adultery with his neighbor's wife, the adulterer and the adulteress shall surely be put to death. And the man that lieth with his father's wife hath uncovered his father's nakedness: both of them shall surely be put to death; their blood shall be upon them. And if a man lies with his daughter in law, both of them shall surely be put to death: they have wrought confusion; their blood shall be upon them).

B. Homosexuality: This is what came in Leviticus 20/13: (If a man also lies with mankind, as he lieth with a woman, both of them have committed an abomination: they shall surely be put to death; their blood shall be upon them).

C. Intercourse with animals: Where it was mentioned in Leviticus 20/15-16: (And if a man lies with a beast, he shall surely be put to death: and ye shall slay the beast. And if a woman approaches unto any beast, and lie down thereto, thou shalt kill the woman, and the beast: they shall surely be put to death; their blood shall be upon them).

These are the sexual acts that are mentioned in the punishment in the Torah, and hence the question arises about whether these acts are criminal only, meanings are other sexual acts outside the scope of punishment and therefore are considered permissible?

An opinion went on to say that sexual acts prohibited by the Torah, and its penalties are exceptions, and they have been mentioned exclusively, and it is not permissible to expand their interpretation or add to them in respect of the principle of legality (no crime, no punishment without law) (Epstein 1967).

This made some believe that the Torah, although it prefers sex within marriage, does not explicitly prohibit it before marriage (Gordon-Bennet 2020).

Rather, rape is not a criminal offense (Skolnik et al. 2007).

Therefore, according to this opinion, Judaism did not know the principle of absolute criminalization for all 
sexual acts. One researcher comments on that, saying: "If the Torah really wanted to act on the principle of absolute criminalization, it would have said: The fornicator and the adulterer, then flog or kill. But it did not say, so it does not want for this. It criminalized the most severe cases, and left the rest of the cases without criminalization." (Al-Batrawi 1992).

However, the other opinion, which appeared after the development of the Talmud, is that the Talmud came to adopt the principle of absolute criminalization of all sexual acts, for it has taken from the Deuteronomy two general rules in this area: the criminal rule for every sexual act which no special text is provided (verse 23:17: There shall be no whore of the daughters of Israel, nor a sodomite of the sons of Israel) And the punitive rule in verse 25:2: (And it shall be, if the wicked man is worthy to be beaten, that the judge shall cause him to lie down, and be beaten before his face, according to his fault, by a certain number. Forty stripes he may give him, and not exceed). The Talmud demands a strict sexual morality (Cohen 1949).

\section{b. Christianity}

The Christian religion adopts the principle of absolute prohibits of all sexual acts that occur outside marriage, based on its embrace of the moral factor associated with the idea of the legitimacy of sexual relationship (Shams al-Din 1994).

Indeed, if we review the texts of the Gospel, we find that Christianity forbade committing adultery (Corinthians 6: 18: Flee fornication. Thessalonians 3: 4: For this is the will of God, even your sanctification, that ye should abstain from fornication). and from its introductions (Matthew 5: 27-28: Ye have heard that it was said by them of old time, Thou shalt not commit adultery. But I say unto you, That whosoever looketh on a woman to lust after her hath committed adultery with her already in his heart). and homosexuality is also forbidden (Romans 1:27: And likewise also the men, leaving the natural use of the woman, burned in their lust one toward another; men with men working that which is unseemly, and receiving in themselves that recompense of their error which was meet). In fact, they considered that sexual acts outside marriage are unclean and must be avoided (2nd Peter 2: 9-10: The Lord knoweth how to deliver the godly out of temptations, and to reserve the unjust unto the day of judgment to be punished. But chiefly them that walk after the flesh in the lust of uncleanness, and despise government. Presumptuous are they, self-willed, they are not afraid to speak evil of dignities).

Thus it became clear that Christianity prohibits all sexual acts except for marriage, but the problem appears in the Christian religion about the right to punishment, so it is noticed that the Gospel, even though it forbids these acts, did not stipulate any penalties for it, so opinions went on to say that Christianity does not give us the right to punish the sinner, given that Corporal punishment does not turn the criminal into a good person, but rather makes him commit his hidden crimes, which means that Christianity is prohibited and not criminalized.

\section{c. Islam}

The Islamic religion prohibits all sexual acts outside marriage. In the sense that Islam follows the principle of the absolute prohibition of all sexual acts, except for acts between married couples. This is what was stated in the Qur'an: (And they who guard their private parts. Except from their wives...) (Al-Mu'minūn: 5,6).

According to the penal system in Islam, any prohibition can be punished. In the field of sexual crimes, he placed the crime of adultery among the hudud crimes, as it is the most serious sexual crime, and it was mentioned in the Qur'an: (The [unmarried] woman or [unmarried] man found guilty of sexual intercourse lash each one of them with a hundred lashes...) (An-Noor:2). As for the rest of the sexual crimes, they are included in the field of Ta'azer crimes, which are crimes that are not stipulated in a text, but they constitute disobedience and contravene the orders of Sharia, and the assessment of their punishment is left to the ruler or judge under certain conditions.

It is worth noting that Islam was strict to the point of prohibiting all acts that it believes lead to the commission of sexual acts, as it follows a preventive strategy according to his view. Including Prohibition of gazing at a non-mahram woman: (Tell the believing men to reduce [some] of their vision and guard their private parts) (An-Noor:30); And the prohibition of seclusion between a man and a foreign woman; The same applies to ordering women to wear concealed clothing and not to show adornment except to the husband: (And tell the believing women to reduce [some] of their vision and guard their private parts and not expose their adornment... and not expose their adornment [i.e., beauty] except to their husbands...) (An-Noor:31). 


\section{CONTEMPORARY LAWS PHILOSOPHY}

There is a wide difference between the philosophy of criminalizing sexual acts in the Heavenly religions and contemporary laws. If the Heavenly religions in the above manner adopt the principle of absolute criminalization of all sexual acts outside marriage, then contemporary laws are the opposite of that as they adopt the principle of sexual freedom as a basis for criminalization. The reason for this difference is due to the difference in the basis that it adopts, while the different religions aim to protect virtue, morals, purity of honor and non-mixing of genealogies, contemporary laws base their criminalization on protecting sexual freedom of individuals, so the act constitutes a crime if involves an assault on the sex freedom of others or in violation of restrictions set for it. Therefore, any sexual act carried out with legal consent and in non-publicity is not criminal because it does not violate anyone's sexual freedom (Al-Shahat 2011).

There is no doubt that the positive legislation's keenness to guarantee personal freedoms and not to interfere in the private affairs of individuals or to violate their secrets made the circle of law much narrower than the circle of morals. The law does not punish all that is deplored by the principles of morality but rather selects some forms of moral crimes that are distinguished from others by seriously damaging the social order, whether directly or indirectly, and imposes appropriate penalties to deter the perpetrators (Al-Dahabi 1997).

\section{JORDANIAN LAW PHILOSOPHY}

Jordanian law has not drawn up a provision that includes the principle it adopts in the area of criminalizing sexual acts. Therefore, revealing his philosophy requires consideration of two matters: general principles of freedom, and provisions that dealt with sexual crimes.

In terms of general principles, according to Article 7 of the Constitution, personal freedom is safeguarded. As a general rule, the basic principle in acts is permissible, because criminalization is the exception, which means that any sexual act that has not been stipulated criminalizing it is considered permissible.

As for the sexual crimes mentioned in the Jordanian Penal Code, the legislator allocated Chapter Seven of the Second Book for it, entitled (Crimes that violate decency and public morals). The first crime is the crime of rape that is achieved through unlawful sexual intercourse between a male and a female without her consent. In order for consent to be considered, all eligibility requirements must be met, including the female reaching the age of eighteen (Articles 292 to 295).

It also criminalized assault, which is any gross sexual act without rape committed on a person without his consent (articles 296 to 299). There is also the crime of indecent act stipulated in Article 320 which criminalizes any sexual act committed in a public place.

Jordanian law still criminalizes adultery (Articles 282-284), and considers it a crime against family morals, but within narrow limits. Even if this crime is committed with the consent, it affects the interest of the family, so it is not permissible to prosecute except with a complaint from either the husband or wife or From the woman's guardian if she is not married.

According to the foregoing, it appears that the Jordanian legislator adopts the principle of sexual freedom, and according to its meaning, any sexual act, regardless of whether it is committed between two adult parties with their consent, is not considered a crime as long as it does not affect the public interest or the private interest.

\section{THE EXTENT TO WHICH JORDANIAN SOCIETY ACCEPTS SEXUAL FREEDOM}

It seems that Jordanian society is still adhering to its social customs and traditions based on Islamic law, so the majority reject the principle of sexual freedom, and to reveal this fact, a questionnaire was designed that contained the main question: Do you support not punishing the perpetrators of sexual acts (outside marriage) among adults if they are satisfied? If the answer is no, then what is the reason?

The questionnaire was distributed to a random sample of (1000) people of both sex (53\% of them are males and the rest are females), all of them are educated, from different geographical areas in Jordan, their ages ranged between $18-50$ years. The proportions of the answers were as follows:

$84 \%$ of the sample support punishment of adults for sexual acts (outside marriage) even if it is with the consent of both parties, and this means that they support the absolute criminalization of sexual acts.

$16 \%$ support the principle of sexual freedom and do not support punishment of perpetrators of 
sexual acts as long as they were committed with consent between two adult parties.

- $\quad$ About $92 \%$ of the supporters of the absolute criminalization of sexual acts attribute this to a religious reason and the rest for social reasons in observance of customs and traditions.

\section{CONCLUSION}

We tried through this article to know the philosophy of Jordanian law, including criminalizing sexual acts and stating its position compared to the monotheistic religions, and the orientation of contemporary laws to adopt the principle of sexual freedom. It was found that the Jordanian legislator sided with the principle of sexual freedom, with the exception of criminalizing adultery, but not on the basis that it is a sexual crime, but on the basis of family rights. It is noted that the Jordanian legislator was not successful in following that principle, because it contravenes a constitutional principle stated in the Jordanian constitution that Islam is the religion of the state, which makes the Jordanian law's orientation regarding sexual crimes completely contrary to the orientation of Islam.

The position of the Jordanian legislator, although influenced by the legislation calling for freedom, but it contradicts all the monotheistic religions that at least agree to prohibit and / or incriminate them for committing sexual acts outside marriage.

To find out the extent of the Jordanian society's acceptance of the position of its legislation in terms of its adoption of the principle of sexual freedom, we designed a questionnaire and distributed it to 1,000 randomly assigned people, and the main result was that the majority of society does not support sexual freedom, and this calls for the Jordanian legislator to reconsider his position, in order to come up with legislation suitable for society.

\section{REFERENCES}

Abu Amer, M. 1985. Criminal Protection for Presentation in Contemporary Legislation. Alexandria: Technical for Printing and Publishing.

Al-Batrawi, A. 1992. The crime of adultery between divine laws and man-made laws. Cairo: Dar Al-Safwa.

Al-Batrawi, A. 1996. Islamic Social Defense. Cairo: Dar Al-Fikr AlArabi.

Al-Dahabi, E. 1997. Sexual Crimes. Second Edition, Cairo.

Al-Shahat, H. 2011. Punitive Law. Cairo: Dar Al-Nahda Al-Arabiya.

Cohen, A. 1949. EVERYMAN'S TALMUD. London.

De Marneffe, P. 2013. Sexual Freedom and Impersonal Value. Criminal Law and Philosophy 7:495-512. https://doi.org/10.1007/s11572-013-9223-z

Epstein, Louis M. 1967. Sex Laws and Customs in Judaism. New York: KTAV Publishing House.

Gordon-Bennett, C. 2020. A Guide to Sex in Judaism. Learn Religions. https://www.learnreligions.com/judaism-on-sex2076785. accessed May 1, 2020.

Green, L. 2013. Should Law Improve Morality?. Criminal Law and Philosophy 7:473-494. https://doi.org/10.1007/s11572-013-9248-3

Hassan, S. 2004. Criminal Protection of Honor. Cairo: Dar AI-Nahda Al-Arabiya.

Hosni, M. 1984. The Right to Preserve Presentation in Islamic Law and the Egyptian Penal Code. Cair: Dar Al-Nahda AlArabiya.

Shams al-Din, A. 1994. Criminal Protection of the Right to Preserve Presentation. PhD thesis: Cairo University.

Skolnik, F., Berenbaum, M. 2007 (editors). Encyclopaedia Judaica. (Second Edition), New York: Keter Publishing House.

\begin{tabular}{lll}
\hline Received on 24-03-2021 & Accepted on 18-05-2021 & Published on 26-05-2021
\end{tabular}

https://doi.org/10.6000/1929-4409.2021.10.128

(c) 2021 Issa and Al-Taraira; Licensee Lifescience Global.

This is an open access article licensed under the terms of the Creative Commons Attribution Non-Commercial License (http://creativecommons.org/licenses/by-nc/3.0/) which permits unrestricted, non-commercial use, distribution and reproduction in any medium, provided the work is properly cited. 